\title{
Cryopreservation of sheep ovarian tissue: Effect of different cryoprotectants and equilibration regimen on ovarian follicles structure
}

\author{
Abdel-Aal, E.S. \\ Sheep and Goats Research Department, Animal Production Research Institute, Dokki, Giza
}

\begin{abstract}
This study compared the efficiency of some cryoprotectant agents (CPAs), including both of exposure time and temperature aiming to determine the effect of cryopreservation on structural integrity of ovine ovarian tissue. This study was carried out at the Laboratory of Reproduction and Biotechnology, Sheep and Goats Research Department, Animal Production Research Institute. A number of 118 sheep ovaries were collected from the local slaughter- house and transported to the laboratory in $0.9 \%$ saline solution. The ovarian cortex was cut into fragments. The selected ovarian fragments (156 fragments) were randomly distributed over the experimental treatments; 12 fragments (as control) for routine histological and electron microscopy examination. The remained fragments (144) were divided into three equal groups according to the studied cryoprotectant agents; ethylene glycol (EG), propylene glycol (PROH) or dimethyl sulfoxide (DMSO). Then they submitted to the vitrification procedure. The obtained results of this study showed that vitrification and freezing/thawing processes negatively affected on integrity of the follicles in the ovarian fragments, where it achieved the highest $(\mathrm{P}<0.05)$ integrity percentage $(85.4 \%)$, when EG was used after 30 min equilibration at room temperature, compared with using DMSO or PROH (75 and 45.7\%, respectively). Whereas, longer exposure time up to $60 \mathrm{~min}$. decreased the integrity of all the groups. Equilibration of ovarian tissue fragments under cooling condition $\left(5^{\circ} \mathrm{C}\right)$ for $30 \mathrm{~min}$, achieved significantly $(\mathrm{P}<0.05)$ lower proportion of integrity in the frozen/thawed ovarian follicle compared to equilibration for $60 \mathrm{~min}$. The percentage of normal preantral follicles (primordial and primary follicles) was $79.3 \%$ in control fragments of ovarian sheep, this percentage was significantly $(\mathrm{P}<0.05)$ reduced after exposure of ovarian tissue to cryopreservation in the presence of EG, DMSO or PROH, under different equilibration periods and temperatures. It can be concluded that EG followed DMSO is the most suited cryoprotectant among these freezing/thawing procedures, equilibration of ovarian tissues for $30 \mathrm{~min}$. resulted in high percentage of intact follicle at room temperature compared to those at $5^{\circ} \mathrm{C}$. Meanwhile, when extending the period to $60 \mathrm{~min}$, the percentage of intact follicle was higher at $5^{\circ} \mathrm{C}$. Finally, the observed follicular damage was rather due to the cryoprotectant than the cryopreservation process itself.

Key Words: Ovarian tissue, equilibration period, cryoprotectant, cropreservation, Sheep
\end{abstract}

\section{INTRODUCTION}

The ability to cryopreserve female gametes has important applications for genetic resources preservation, as well as for conservation of endangered animals and economically important breeds. Though oocyte cryopreservation was frequently attempted, it consistently had poor results (Oktay, et al., 1998). An alternative strategy for storing female germ cells is cryopreservation of ovarian tissue, which enables the storage of large numbers of oocytes (within primordial follicles). Several characteristics make the ovarian tissue less susceptible to cryoinjury, where it contain mixture of different cell types: oocytes, granulosa cells, epithelial cells, different stage of follicles, fibroblasts... This represents a major difficulty because the optimum kinetic of cooling is differ for each cell type. So, cryopreservation protocol for ovarian tissue represents a compromise between the requirements of the different constitutive cells, than cryopreservation of isolated cells (Lucci et al., 2004). Cryopreservation of ovarian tissue is a challenging procedure, since not only the follicles but also different cell types are subjected to the toxic effect of the cryoprotectant and deleterious consequences of the freezingthawing process (Marsella, et al., 2008). Cryoprotectant agents (CPA) are some chemical 


\section{Cryopreservation of sheep ovarian tissue: Effect of different cryoprotectants and equilibration regimen on ovarian follicles structure}

compounds able to prevent cells or tissues from damage due to freezing. Proper penetration of the cryoprotectant through the stroma and granulosa cells to the oocytes is necessary, to avoid possible toxicity of the CPA. Ice crystal formation has to be minimized by choosing optimal freezing and thawing rates (Fuller and Paynter, 2004). There are many CPAs, such as glycerol (G), ethylene glycol (EG), propylene glycol (PROH), dimethyl sulfoxide (DMSO) commonly used within this category (Wowk et al., 2000). Gosden et al. (1994) used dimethyl sulphoxide as a CPA for sheep ovarian tissue by slow freezing program. Transplantation of frozen-thawed tissue slices resulted in cyclic activity and pregnancies, with one live lamb born. Since then, several successful studies regarding freezing of ovarian tissue of several animal species, such as sheep (Almodin et al. 2004), goats (Rodrigues et al., 2004), and zebu bovine (Lucci et al., 2004) have been performed. An equilibration period was necessary to achieve $\mathrm{CPA}$ penetration into the tissue, and allow the inner cell water to be replaced partly by the permeating CPAs. However, the CPAs can be a damaging factor to the cells, especially when it used at high concentrations. The toxicity can reduced by decreasing the time or temperature of the equilibration step (Karlsson and Toner, 1996). But equilibration at low temperatures requires increasing the exposition time to freezing solution. Furthermore, the CPAs may have dramatic osmotic effects upon the cells during their addition and their removal. The aim of this study was to evaluate comparatively the efficiency of different CPAs and both of exposure time and temperature to determine the effect of cryopreservation on structural integrity of ovine ovarian tissue.

\section{MATERIALS AND METHODS}

This study was carried out at the Laboratory of Reproduction and Biotechnology, Animal Production Research Institute. Sheep and Goats Research Department, during the period from November, 2018 to December, 2019.

\section{Collection and processing of sheep ovarian tissue:}

A number of 118 sheep ovaries were collected from the local slaughter- house and transported to the laboratory in $0.9 \%$ saline solution. Upon arrival to the laboratory, Ovaries were trimmed from adhering tissue and rinsed in $70 \%$ alcohol and twice in phosphate-buffered saline (PBS). The ovarian cortex were dissected from medullar tissues by scalpel and cut into four fragments (about $1 \mathrm{~mm}^{3}$ ). The fragments placed in PBS supplemented with $0.1 \% \quad(\mathrm{v} / \mathrm{v})$ penicillin/streptomycin (Gibco, Paisley, UK) at room temperature $\left(25^{\circ} \mathrm{C}\right)$, which were randomly distributed over the experiments.

\section{Experimental sampling:}

The selected ovarian fragments (156 fragments) were randomly distributed over the experimental treatments. The first 12 fragments (as control); 6 of them was fixed in $4 \%$ paraformaldehyde for $12 \mathrm{~h}$ for routine histological examination, and the other 6 fragments were fixed in $2.5 \%$ glutaraldehyde in phosphate-buffered saline $(\mathrm{pH}$ 7.4) for routine electron microscopy examination. The remaining fragments were submitted to the vitrification procedure.

\section{Dehydration regimen and vitrification procedure}

Dehydration prior to vitrification was performed using two steps method according to Gookv and Edgar (1999). Briefly, 144 fragments divided according to the studied cryoprotectant agents into three equal groups and placed into 12 Falcon tubes $(15 \mathrm{ml})$ (Becton Dickinson, Bedford, MA, USA).(Fig. 1).

In these groups the ovarian fragments were dehydrated (equilibrated) in two stepwise manners as follows: The fragments' groups were submitted to vitrification solution I (VSI); consisted of basic medium (TCM- 199 with $10 \%$ fetal bovine serum) $+1.5 \mathrm{M}$ from one of the following cryoprotectant agents; EG, DMSO or PROH. For different equilibration times (15 or $30 \mathrm{~min}$.) and at different temperature $\left(25\right.$ or $\left.5^{\circ} \mathrm{C}\right)$, and then submitted to vitrification solution 2 (VS2); consisted of basic medium (TCM- 199 with $10 \%$ fetal bovine serum) $+3 \mathrm{M}$ from one of 
Fig.1. Experimental protocol to test the effect of different cryoprotectant agents and equilibration conditions (period; 30 or $60 \mathrm{~min}$,) and (temperatures; 25 or $5^{\circ} \mathrm{C}$ ) on the cryopreservation of ewes ovarian tissue.

(Equilibration period: is the overall time of exposure to VS1 + VS2)

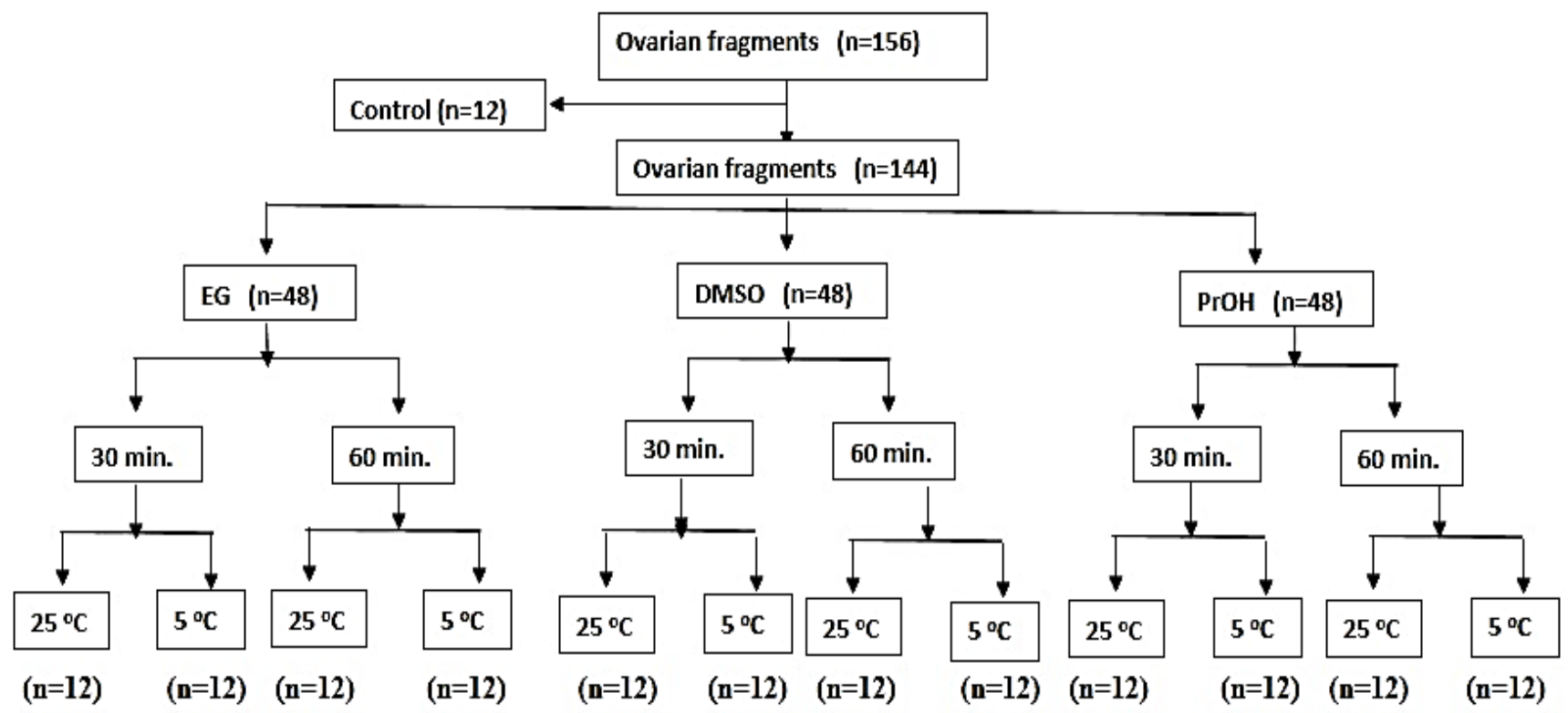

the following cryoprotectant agents; EG, DMSO or PROH, for the same equilibration times and temperatures as the previous step. The chart in Fig. (1) Illustrates the experimental design.

\section{Freezing and thawing procedures}

For freezing, sheep ovarian fragments of each treatment were placed into cryo-vail that exposed for 15 min to liquid nitrogen vapor ($135^{\circ} \mathrm{C}$ ), and then were plunged directly into liquid nitrogen $\left(-196^{\circ} \mathrm{C}\right)$ and stored for at least $24 \mathrm{~h}$ till the time of examination. For thawing, the vials took from the liquid nitrogen, and warmed at room temperature for $30 \mathrm{~s}$, then placed into $37{ }^{\circ} \mathrm{C}$ water bath until melting, followed by immediate transfer of fragments into $15 \mathrm{ml}$ Falcon tubes containing $5 \mathrm{ml}$ of basic medium with descending concentrations of sucrose $(0.5,0.25$, and $0.125 \mathrm{M})$ for $5 \mathrm{~min}$. at $37^{\circ} \mathrm{C}$, then transferred into basic medium for 10 min 2 times, then fragments were fixed for histological and ultra-structural examination.

\section{Histological evaluation}

The vitrified ovarian fragments fixed in $10 \%$ formaldehyde solution. The fixed fragments were dehydrated in ethanol, then clarified with xylene and embedded in paraffin wax and serially sectioned to a thickness of $4 \mu \mathrm{m}$. The $10^{\text {th }}$ section of each ovarian fragment was mounted on glass slides and stained with haematoxylin eosin. The stained sections were examined using light microscope at 400x magnification. Follicles were classified as normal when contain an intact oocyte and granulosa cells, or as degenerated if has one or more of the following aspects; condensed oocyte nucleus; signs of shrinkage or swelling oocyte; nonhomogeneous ooplasm; pyknotic nuclei in the granulosa cells, or low cellular density. The numbers and percentages of primordial, primary and secondary follicles recorded separately for each category.

\section{Electron microscope}

Investigation and examination of ultra-structural details of different ovarian specimens carried out in "The Electron Microscopy (EM) unit at Assiut University". Vitrified and non-vitrified ovarian 


\section{Cryopreservation of sheep ovarian tissue: Effect of different cryoprotectants and equilibration regimen on ovarian follicles structure}

fragments were collected, equilibrated for 30 min and fixed in $2.5 \%$ glutaraldehyde in a phosphate buffer saline $(\mathrm{pH} 7.4)$ at room temperature for $5 \mathrm{~min}$, kept at $4^{\circ} \mathrm{C}$ for an additional hour and then post-fixed using $1 \%$ osmium tetroxide (OsO4; Plano, Wetzlar, Germany) for $1 \mathrm{~h}$ at $4^{\circ} \mathrm{C}$. Sample dehydration performed in ascending grades of acetone (35, $50,75,95$, and $100 \%$ ) for 10 min. A mixture of resin and acetone used for sample infiltration. Subsequently, samples polymerized in $100 \%$ resin at $60^{\circ} \mathrm{C}$ for 20 hours.

Semi-thin sections $(0.5 \mu \mathrm{m})$ stained with toluidine blue for the light microscope. Ultrathin sections $(60-80 \mathrm{~nm})$ contrasted with uranyl acetate for $10 \mathrm{~min}$., and then examined using transmission electron microscope (Zeiss, Gottingen, Germany) at $80 \mathrm{kV}$. This experiment was replicated five times at different dates. Due to the heterogeneity of follicle distribution in the ovarian cortex among tissues, only cortical pieces with preantral, primary and secondary follicles were selected.

\section{Statistical analysis:}

The comparison of the percentages of the morphologically normal follicles in different treatments with relation to the control was analyzed by a factorial design using ANOVA test of SAS (1996). Values were considered statistically significant at $\mathrm{P}<0.05$.

\section{RESULTS}

When ovarian tissues exposed to the vitrification solutions (VSs) containing the cryoprotectant agents; EG, DMSO or PROH, the proportion of morphologically normal follicles was equilibrated at room temperature $\left(25^{\circ} \mathrm{C}\right)$., Vitrification and freezing/thawing processes negatively affected the integrity of the follicles in the ovarian fragments. The highest $(\mathrm{P}<0.05)$ integrity percentage $(85.4 \%)$ was achieved when EG used after 30 min equilibration, whereas, longer exposure time (to $60 \mathrm{~min}$ ) decreased the integrity to $(40 \%)$. The results in table (1) also revealed that EG can protect the ovarian tissue from the cryo-damage and the differences were significantly $(\mathrm{P}<0.05)$ higher than DMSO and PROH (85.4 vs. 75 and 45.7\%, respectively). The differences in integrity refer to that extending the exposure period, when we used DMSO and PROH, took the same pattern as EG. Equilibration of ovarian tissue fragments under cooling condition $\left(5^{\circ} \mathrm{C}\right)$ for $30 \mathrm{~min}$, achieved significantly $(\mathrm{P}<0.05)$ higher proportion of integrity in the frozen/thawed ovarian follicles with EG $(42.5 \%)$ compared to DMSO and PROH (33.6 and $34.2 \%$, respectively). In contrast to what happened at $25^{\circ} \mathrm{C}$, this proportion considerably increased when the equilibration period extended to $60 \mathrm{~min}$. The EG and DMSO groups revealed significantly higher integrity percentage after 60 min compared with PROH group after30 min (60.5 and62.7 vs. 42.5 and $33.6 \%$. respectively). It is worth noting that exposure time $(60 \mathrm{~min})$ at $5^{\circ} \mathrm{C}$ positively increased the percentage of intact follicles (Table 2).

Table 1. Effect of exposure time to cryoprotectant agents at $25^{\circ} \mathrm{C}$ on the integrity of primordial follicles in vitrified-thawed sheep ovarian fragments

\begin{tabular}{|l|c|c|c|c|c|c|}
\hline \multirow{2}{*}{ Cryoprotectant agent } & \multicolumn{2}{|c|}{ Exposure time 30 min. } & \multicolumn{2}{c|}{ Exposure time 60 min. } \\
\cline { 2 - 7 } & $\begin{array}{c}\text { No. } \\
\text { ovarian } \\
\text { fragments }\end{array}$ & $\begin{array}{c}\text { No. } \\
\text { examined } \\
\text { follicles }\end{array}$ & $\begin{array}{c}\text { Integrity \% } \\
\text { (No. follicles) }\end{array}$ & $\begin{array}{c}\text { No. } \\
\text { ovarian } \\
\text { fragments }\end{array}$ & $\begin{array}{c}\text { No. } \\
\text { examined } \\
\text { follicles }\end{array}$ & $\begin{array}{c}\text { Integrity \% } \\
\text { (No. follicles) }\end{array}$ \\
\hline EG $(1.5 \mathrm{M}+3 \mathrm{M})$ & 12 & 123 & $\begin{array}{c}85.4^{\mathrm{aA}} \\
(105)\end{array}$ & 12 & 115 & $\begin{array}{c}40.0^{\mathrm{bA}} \\
(46)\end{array}$ \\
\hline DMSO $(1.5 \mathrm{M}+3 \mathrm{M})$ & 12 & 118 & $\begin{array}{c}75.0^{\mathrm{aB}} \\
(88)\end{array}$ & 12 & 129 & $\begin{array}{c}44.2^{\mathrm{bA}} \\
(57)\end{array}$ \\
\hline PROH $(1.5 \mathrm{M}+3 \mathrm{M})$ & 12 & 127 & $\begin{array}{c}45.7^{\mathrm{aC}} \\
(58)\end{array}$ & 12 & 98 & $27.6^{\mathrm{bB}}$ \\
$(27)$
\end{tabular}

Values within rows $(\mathrm{a}, \mathrm{b})$ are different $(\mathrm{P}<0.05)$ and values within columns $(\mathrm{A}, \mathrm{B}, \mathrm{C})$ are different $(\mathrm{P}<0.05)$. 
Table2. Effect of exposure time to cryoprotectant agents at $5^{\circ} \mathrm{C}$ on the integrity of primordial folliclesin vitrified-thawed sheep ovarian fragments

\begin{tabular}{|l|c|c|c|c|c|c|}
\hline \multirow{2}{*}{ Cryoprotectant agent } & \multicolumn{3}{|c|}{ Exposure time 30 min. } & \multicolumn{3}{c|}{ Exposure time 60 min. } \\
\cline { 2 - 7 } & $\begin{array}{c}\text { No. } \\
\text { ovarian } \\
\text { fragments }\end{array}$ & $\begin{array}{c}\text { No. } \\
\text { examined } \\
\text { follicles }\end{array}$ & $\begin{array}{c}\text { Integrity \% } \\
\text { (No. follicles) }\end{array}$ & $\begin{array}{c}\text { No. } \\
\text { ovarian } \\
\text { fragments }\end{array}$ & $\begin{array}{c}\text { No. } \\
\text { examined } \\
\text { follicles }\end{array}$ & $\begin{array}{c}\text { Integrity \% } \\
\text { (No. follicles) }\end{array}$ \\
\hline EG (1.5 M +3 M) & 12 & 129 & $\begin{array}{c}42.5^{\mathrm{bA}} \\
(54)\end{array}$ & 12 & 127 & $\begin{array}{c}60.5^{\mathrm{aA}} \\
(78)\end{array}$ \\
\hline DMSO (1.5 M + 3 M) & 12 & 131 & $\begin{array}{c}33.6^{\mathrm{bB}} \\
(44)\end{array}$ & 12 & 126 & $\begin{array}{c}62.7^{\mathrm{aA}} \\
(79)\end{array}$ \\
\hline PROH (1.5 M + 3 M) & 12 & 120 & $\begin{array}{c}34.2^{\mathrm{aB}} \\
(41)\end{array}$ & 12 & 118 & $\begin{array}{c}39.8^{\mathrm{aB}} \\
(47)\end{array}$ \\
\hline
\end{tabular}

Values within rows $(\mathrm{a}, \mathrm{b})$ are different $(\mathrm{P}<0.05)$ and values within columns $(\mathrm{A}, \mathrm{B}, \mathrm{C})$ are different $(\mathrm{P}<0.05)$.

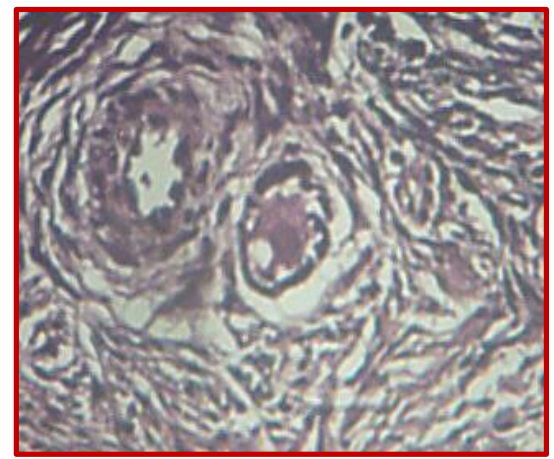

Fig.2. Histological section of fresh normal primordial and primary follicle from sheep ovarian tissue (control) stained with HE. Magnification: $600 \mathrm{X}$

Equilibration for 30 min.

At $2^{\circ} \mathrm{C}$

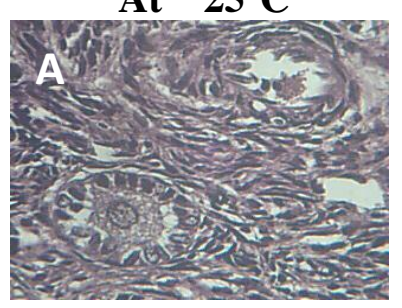

EG

DMSO
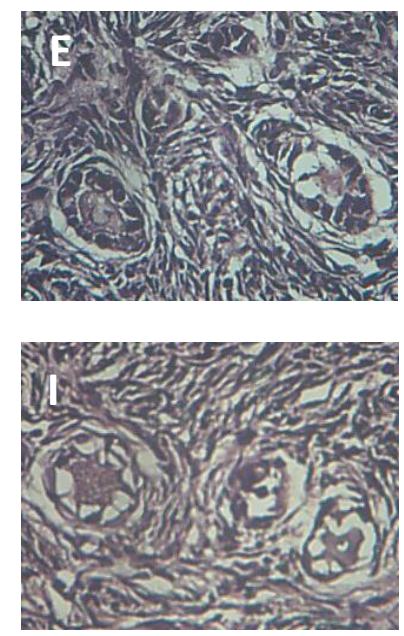

At $5^{\circ} \mathrm{C}$
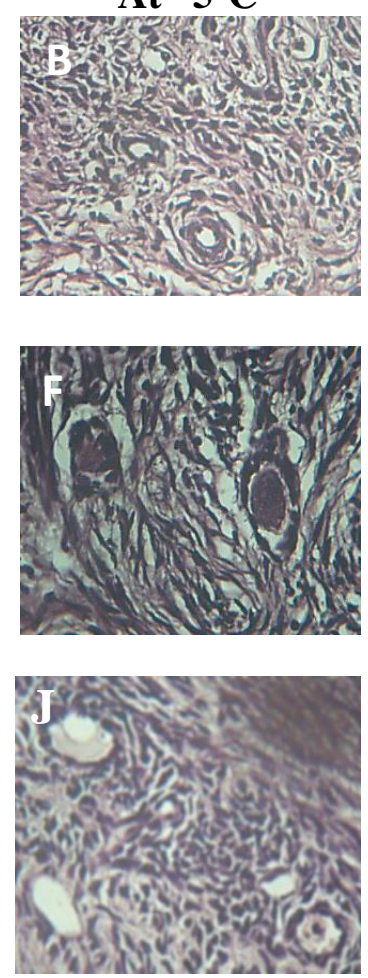

Equilibration for $60 \mathrm{~min}$.
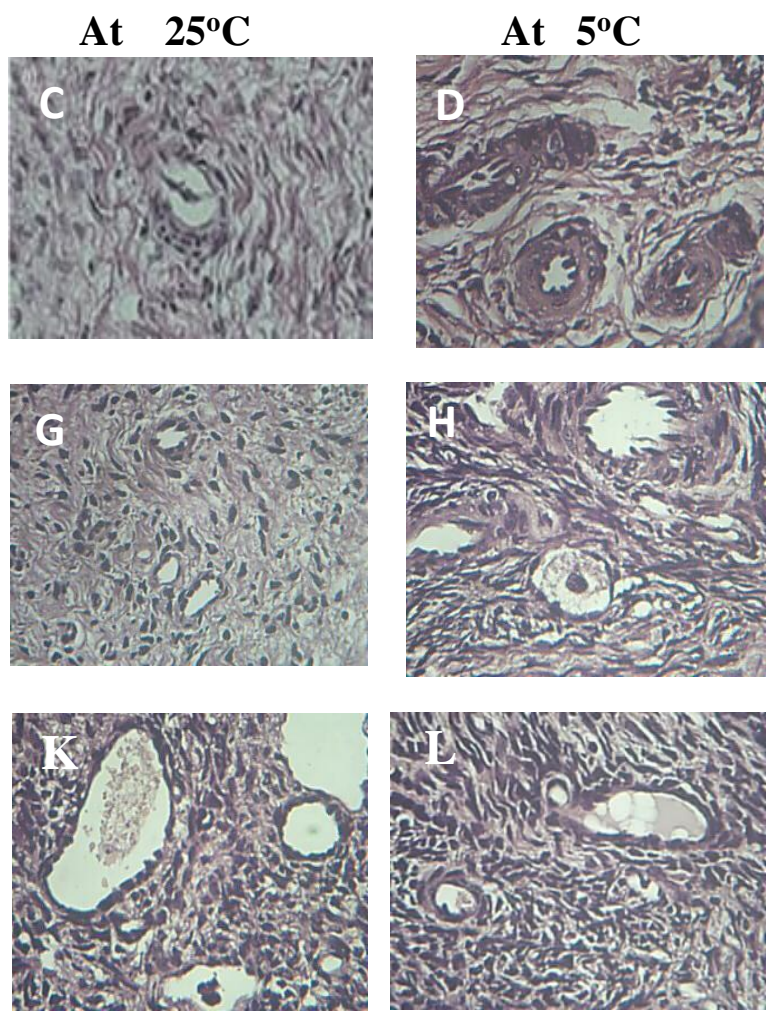

Fig.3. Histological sections of sheep normal and atretic primordial primordial follicles, Morphologically normal sheep follicles after exposure to VS1 and VS2 and cryopreservation, when using EG, DMSO and PrOH, under different equilibration periods (30 and $60 \mathrm{~min}$.) at room temperature or $5^{\circ} \mathrm{C}$. 


\section{Cryopreservation of sheep ovarian tissue: Effect of different cryoprotectants and equilibration regimen on ovarian follicles structure}

Histological examination of the sheep ovarian tissue showed normal primordial and primary follicle from ovarian tissue (control) (Fig. 2). The histological analysis of ovarian tissues, illustrated the morphology of normal follicles which characterized by a round or oval oocyte, presenting a well-delimited nucleus with uncondensed chromatin, surrounded by healthy granulosa cells closely to the oocyte (Fig. 3A). Among morphologically abnormal follicles, two types of degeneration could be distinguish. This observed with high survival rate in ovarian tissue exposed and cryopreserved in 1.5 and $3 \mathrm{M} \mathrm{EG}$ for $30 \mathrm{~min}$ at room temperature (Fig 3-A) and 60 min at $5^{\circ} \mathrm{C}$ (Fig 3-D), and with lower frequency in tissue exposed to or cryopreserved in $\mathrm{PROH}$, (Fig 3-K and L).

The kind of degeneration was also observed in the tissue exposed and cryopreserved in $\mathrm{PROH}$ and DMSO especially with long equilibration period (60 $\mathrm{min}$ ) either at room temperature of at $5^{\circ} \mathrm{C}$ (Fig 3- G, H, K and L). The best histological analysis of the vitrified - cryopreserved ovarian tissue, achieved with 30 min equilibration period at room temperature, regardless the cryoprotectant type (Fig 3- A, E and I). On the other hand, the worst histological sections were found in fragment equilibrated for $60 \mathrm{~min}$ at room temperature(Fig 3-C,G,K), where degeneration in these sections was characterized by shrinkage of the oocyte and granulosa cells, detachment of the follicle from the surrounding stroma, loss of contact between oocyte and granulosa cells. This type of degeneration was observed most often in preantral follicles from ovarian tissue cryopreserved in $\mathrm{PROH}$.

Table3. Normal preantral follicles (\%) of ovarian fragments for untreated (controls) and ovarian fragments that were treated with cryoprotectant and frozen/thawed (as determined by histological evaluation).

\begin{tabular}{|c|c|c|c|c|c|}
\hline \multirow{2}{*}{$\begin{array}{c}\text { Equilibration } \\
\text { period }\end{array}$} & \multirow{2}{*}{$\begin{array}{l}\text { Equilibration } \\
\text { Temperature }\end{array}$} & \multicolumn{3}{|c|}{ Cryoprotectant agents } & \multirow{2}{*}{ Control } \\
\hline & & EG & DMSO & PROH & \\
\hline \multirow{2}{*}{$30 \mathrm{~min}$} & $25^{\circ} \mathrm{C}$ & $\begin{array}{c}62.9^{\mathrm{aA}} \\
(95 / 151)\end{array}$ & $\begin{array}{c}60.7^{\mathrm{aA}} \\
(96 / 158)\end{array}$ & $\begin{array}{c}46.8^{\mathrm{bA}} \\
(72 / 154)\end{array}$ & \multirow{4}{*}{$\begin{array}{c}79.3 \\
(115 / 14 \\
5)\end{array}$} \\
\hline & $5^{\circ} \mathrm{C}$ & $\begin{array}{c}55.4^{\mathrm{aA}} \\
(82 / 148)\end{array}$ & $\begin{array}{c}54.1^{\mathrm{aA}} \\
(79 / 146)\end{array}$ & $\begin{array}{c}38.3^{\mathrm{bB}} \\
(57 / 149)\end{array}$ & \\
\hline \multirow{2}{*}{$60 \mathrm{~min}$} & $25^{\circ} \mathrm{C}$ & $\begin{array}{c}38.3^{\mathrm{abB}} \\
(62 / 162) \\
\end{array}$ & $\begin{array}{c}42.1^{\mathrm{aB}} \\
(64 / 152) \\
\end{array}$ & $\begin{array}{c}29.1^{\mathrm{bC}} \\
(43 / 148)\end{array}$ & \\
\hline & $5^{\circ} \mathrm{C}$ & $\begin{array}{c}41.9^{\mathrm{aB}} \\
(65 / 155)\end{array}$ & $\begin{array}{c}44.3^{\mathrm{aB}} \\
(66 / 149)\end{array}$ & $\begin{array}{c}32.5^{\mathrm{bBC}} \\
(51 / 157)\end{array}$ & \\
\hline
\end{tabular}

Values within rows $(\mathrm{a}, \mathrm{b})$ are different $(\mathrm{P}<0.05)$ and values within columns $(\mathrm{A}, \mathrm{B}, \mathrm{C})$ are different $(\mathrm{P}<0.05)$.

The percentage of normal preantral follicles (primordial and primary follicles) were $79.3 \%$ in control ovarian fragments of sheep. This percentage was significantly $(\mathrm{P}<0.05)$ reduced after exposure of ovarian tissue to cryopreservation in the presence of EG, DMSO or $\mathrm{PROH}$, under different equilibration periods and temperatures (Table 3). After freezing/thawing, the percentages of normal preantral follicles in sheep ovarian fragments were significantly $(\mathrm{P}<0.05)$ higher by using EG and DMSO compared to PROH under different equilibration conditions. Equilibration periods at the same equilibration temperature affected significantly on the proportion of normal preantral follicles with all cryoprotectant agents, where it was higher at $30 \mathrm{~min}$ than at $60 \mathrm{~min}$. Equilibration temperatures at the same equilibration period took different trend, where it was significant at room temperature $\left(25^{\circ} \mathrm{C}\right)$, the percentage of normal preantral follicle was significantly higher $(\mathrm{P}<0.05)$ when the ovarian fragments equilibrated for $30 \mathrm{~min}$, but extending the period to $60 \mathrm{~min}$ made the percentage reduced obviously. In contrast, equilibration at $5^{\circ} \mathrm{C}$, the percentage of normal preantral follicles increased but not significant when equilibration period was $60 \mathrm{~min}$. 


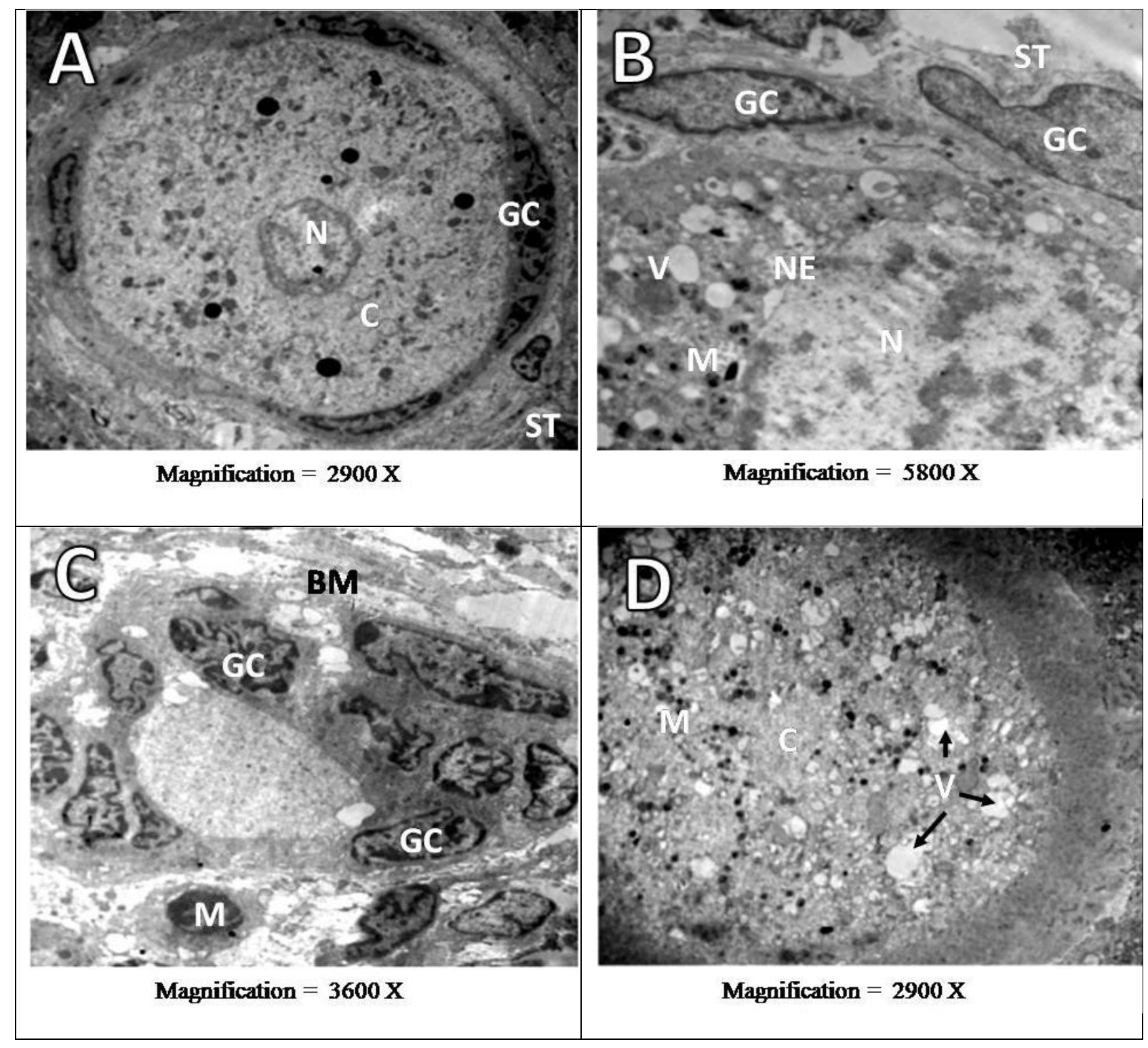

Fig.4. Transmission electron microscopy images of follicles in the fragments of vitrified tissue with EG, DMSO and PROH, under different equilibration periods (30 and $60 \mathrm{~min}$.) at room temperature $\left(25^{\circ} \mathrm{C}\right)$ or $5{ }^{\circ} \mathrm{C}$

(O: oocyte; N: nucleus; GC: granulosa cell, M: mitochondria, V: vacuole, BM: basement membrane, NE: nuclear envelop, ST: stroma tissue, CM: cell membrane.)

The ultrastructural analysis showed that follicles from the fresh control group (Fig. 4A) and vitrified follicles with EG, DMSO and $\mathrm{PROH}$, under different equilibration periods (30 and 60 min.) at room temperature $\left(25^{\circ} \mathrm{C}\right)$ or $5{ }^{\circ} \mathrm{C}$, were similar, presenting oocytes with a large central nucleus well-defined by a nuclear envelope. Organelles were uniformly distributed throughout the homogeneous cytoplasm, with mitochondria being the most evident organelle, and granulosa cells were normal in appearance. In the fresh control group (Fig. 4A), it is possible to see some vesicles. Whereas, the ultrastructure of vitrified follicle showed some discreet changes, like a slight shrinkage in the nuclear envelope. Conversely, more drastic alterations could be observed during ultrastructure analysis of fragments equilibrated in EG for $30 \mathrm{~min}$ at $25^{\circ} \mathrm{C}$ (Fig. 5A), or DMSO and PROH for $30 \mathrm{~min}$ at $25^{\circ} \mathrm{C}$ (Fig. 5B-D) For example, oocytes exhibited cytoplasm vacuolization with a granulated appearance andcontained empty spaces (Fig. 5C). In the $\mathrm{PROH}$ follicles, granulose cells had a loss of cytoplasmic content. 


\section{Cryopreservation of sheep ovarian tissue: Effect of different cryoprotectants and equilibration regimen on ovarian follicles structure}

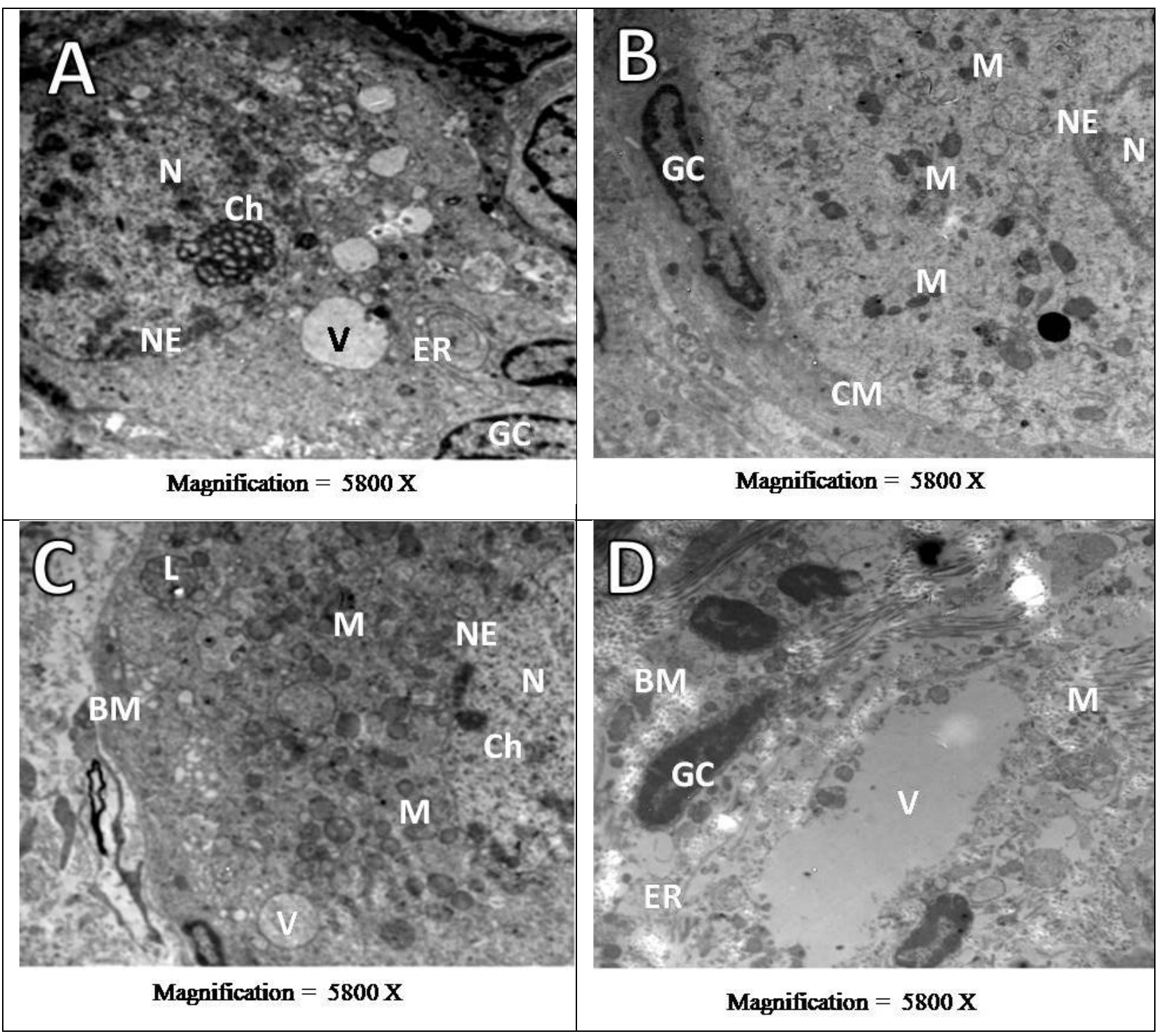

Fig.5. Transmission electron microscopy images of follicles in the fragments of vitrified tissue with EG, DMSO and $\mathrm{PROH}$, under different equilibration periods (30 and $60 \mathrm{~min}$.) at room temperature $\left(25^{\circ} \mathrm{C}\right)$ or $5{ }^{\circ} \mathrm{C}$

(O: oocyte; N: nucleus; GC: granulosa cell, M: mitochondria, ER: endoplasmic reticulum V: vacuole, BM: basement membrane, NE: nuclear envelop, L: lysosome, Ch: chromatin, CM: cell membrane.)

Vitrification of sheep ovarian tissue for $60 \mathrm{~min}$ at room temperature $\left(25^{\circ} \mathrm{C}\right)$, resulted in the greatest ultrastructural abnormalities with vacuolated follicles and the majority of organelles lost in the oocyte cytoplasm (Fig. 5B), which presumably left empty spaces in the oocyte cytoplasm content. The ovarian stromal area also had signs of degeneration, with largely vacated areas (Fig. 5B).

There was no difference between the degeneration rates of primordial, primary and secondary follicles. When viewed with the electron microscope, follicles from the control (Fig. 5A) had oocytes with a large nucleus well delimited by the nuclear envelope. Numerous mitochondria, a few cisternae of smooth endoplasmic reticulum and Golgi apparatus, and a few vesicles were evenly distributed throughout a homogeneous cytoplasm. Granulosa cells had many elongated mitochondria, abundant smooth and rough endoplasmic reticulum and Golgi apparatus, were tightly connected to the oocyte. Follicles cryopreserved in different cryoprotectant agents (Fig. 5A-D) had ultrastructure very similar to the control, with no evident alterations. 


\section{DISCUSSION}

The period of time between mixing the cryoprotectant with the ovarian tissues and beginning of the cooling process is called the equilibration period. Histological examination and ultrastructure analysis of ovine follicles were evaluated after exposure to and cryopreservation of ovarian tissue in presence of two concentrations (1.5 and $3.0 \mathrm{M})$ of ethylene glycol, dimethyl sulphoxide and propylene glycol under different equilibration periods (30 and $60 \mathrm{~min})$ at room temperature $\left(25^{\circ} \mathrm{C}\right)$ or $5^{\circ} \mathrm{C}$.

Vitrification and freezing/thawing processes affected negatively on integrity of the follicles in the ovarian fragments (Table 1 and 2), where the effect of type of cryoprotectant agents and equilibration time and temperature, was very clear. Histological studies facilitate the identification of the primary signs of follicular integrity and atresia, like cytoplasmic damage, detachment of granulosa cells from the oocyte and irregularity of the basement membrane (Demirci et al., 2002). Sheep ovarian tissue previously equilibrated in EG before cryopreservation achieved the higher integrity rate followed by DMSO, either for 30 or $60 \mathrm{~min}$. The previous results agreed with Newton et al. (1998) reported that EG and DMSO are the best cryoprotectants for ovarian tissue. Whereas, both cryoprotectants (EG and DMSO) have low molecular weight, which permits a faster penetration than that observed with $\mathrm{PROH}$, which also explain our results, therefore, previous studies have shown that during the equilibration phase, after the addition of cryoprotectant media but prior to the freezing process, cells initially shrink as water flows out, and subsequently swell as water and cryoprotectant agent enter (Agca et al., 2002). Considering the toxicity and the osmotic effect of cryoprotectant agents, we suggest that both EG and DMSO can efficiently replace some water molecules in the cell but, after being stored at low temperatures for a long period, follicles still appearing viable became more sensitive to the in/out water and cryoprotectant flows, being the EG the less damaging cryoprotectant. For most tissues, equilibration should occur for at least 15 minutes, but not longer than 45-60 minutes. The cryoprotective agent may be toxic to the cells if the equilibration time is too long (Santos, et al., 2006). This can be acquired by using cryoprotectants with high viscosity property like EG and PROH. However, PROH have a variety of diverse metabolic effects such as cellular release of lactate and consequent acidification (Scholmerich et al., 1989). Previous cooling at $20{ }^{\circ} \mathrm{C}$ for $1 \mathrm{~h}$ (protocol 1 ) followed by freezing in presence of 1.5 M EG or DMSO, as well as storage at $4{ }^{\circ} \mathrm{C}$ for $24 \mathrm{~h}$ (protocol 2) before cryopreservation using 1.5 M EG did not reduce percentages of viable preantral follicles when compared with control (Celestino, et al., 2008). On the other hand, DMSO has low viscosity, which does not modify the structure of the freezed concentrated material at rapid rates of cooling, offering poor protection for these cells compared to EG. Adams et al. (2003) observed that the permeability of cryoprotectant agents in unfertilized eggs at $20{ }^{\circ} \mathrm{C}$ is adequate for $\mathrm{PROH}$ penetration and that a relative short exposure time is required to minimize toxic effects. Although histological analysis had shown that after freezing and thawing procedures, the lowest percentages of degenerating sheep follicles were observed with EG or DMSO as cryoprotectants. Paynter et al. (1999) also found that bovine oocytes cryopreserved in DMSO did not undergo ultrastructural cell damage.

Transmission of electron microscopy (TEM) images revealed that the basement membrane, and also important structures as mitochondria, endoplasmic reticulum, oocyte nuclei, and granulosa cells were preserved even after previous cooling and freezing-thawing. Preantral follicles subjected to cryopreservation in EG showed decreased numbers of mitochondria and numerous vesicles in their oocyte that was extremely vacuolated. Similar results obtained by Matos et al. (2004) after cooling of sheep preantral follicles at $20^{\circ} \mathrm{C}$ for about $24 \mathrm{~h}$ in TCM 199. Another author has emphasized that normal sheep oocytes contain a larger number of vacuoles (Tassel and Kennedy, 1980), but in oocytes showing signs of degeneration, these vacuoles become more numerous. The latter characteristic has generally considered as an atretic sign in oocytes (Van Den Hurk et al., 


\section{Cryopreservation of sheep ovarian tissue: Effect of different cryoprotectants and equilibration regimen on ovarian follicles structure}

1998), granulosa cells (Hay et al., 1976) and cumulus cells (Assey et al., 1994), and may represent endoplasmic reticulum swelling. Alternatively, these vacuoles may represent altered mitochondria as observed in cryopreserved bovine oocytes by Lucci et al. (2004). Silva et al. (2001) reported that mitochondria with extensive swelling and disappearance of their cristae, as well as endoplasmic reticulum with increased volume, were the first signs of degeneration in goat preantral follicles. TEM studies with cryopreserved bovine (Fuku et al., 1995) oocytes showed that the presence of numerous vesicles led to cellular rupture, possibly due to an increase of the cellular volume caused by osmotic shock (Asada et al., 2000). Thus, the damage to follicular cell organelles, as visualised at the ultrastructural level, could be the cause of failure in further development of apparently normal cells (Cocero et al., 2002).

Even with the protecting effect of the cryoprotectant provided, damage can sometimes occur due to osmotic stress or chemical toxicity, especially when cryoprotective agents are used at very high concentrations (Rodrigues et al., 2004)

\section{CONCLUSION}

The present study confirmed that EG followed DMSO is the most suited cryoprotectant in this freezing/thawing procedure, preserving sheep follicles within ovarian tissue. Equilibration of ovarian tissues for $30 \mathrm{~min}$. at room temperature resulted in high percentage of intact follicle compared to those at $5^{\circ} \mathrm{C}$. the same positive results were obtained when extending the equilibration period to $60 \mathrm{~min}$. at $5^{\circ} \mathrm{C}$. The observed follicular damage was rather by the cryoprotectant than the cryopreservation process itself. The highest integrity rate of preantral follicles was achieved with EG, and the highest damage was by using PROH. Finally, with further improvement of the cryopreservation protocol, it will be possible to preserve sheep ovarian follicles for a long period and to use them, after thawing, for in vitro growth, maturation and fertilization programs or transplantation studies.

\section{ACKNOWLEDGEMENT}

The author is greatly thankful to Dr. Eitedal H. El-Sayed and Dr. Medhat M. Madboly for their scientific contributions in the experiment, and their advices are deeply appreciated.

\section{REFERENCES}

Adams, S.L., Kleinhans, F.W., Mladenov, P.V., Hessian, P.A. (2003). Membrane permeability characteristics and osmotic tolerance limits of sea urchin (Evechinus chloroticus) eggs. Cryobiology 47, 1-13.

Agca, Y., Gilmore, J., Byers, M., Woods, E.J., Liu, J. and Critser, J.K., (2002). Osmotic characteristics of mouse spermatozoa in the presence of extenders and sugars. Biol. Reprod. 67, 1493-1501.

Almodin, C. G.; Minguetti-Camara, V. C.; Meister, H.; Ceschin, A. P.; Kriger, E. and Ferreira, J. O. (2004). Recovery of natural fertility after grafting of cryopreserved germinative tissue in ewes subjected to radiotherapy. FertilSteril, Vol.81, No.1, pp: 160-164,

Asada, M., Horri, M., Mogo, T., Fukui, Y., Ishikawa, H. and Ohsumi, S., (2000). In vitro maturation and ultrastructural observation of cryopreserved minke whale (Balaenoptera acutorostrata). Biol. Reprod. 62, 253-259

Assey, R.J., Hytell, P., Greve, T. and Purwantara, B., (1994). Oocyte morphology in dominant andsubordinate follicles.Mol. Reprod. Dev. 37, 335-344

Celestino, J. J., Santos, R. R, Lopes, C. A.,Martins, F. S.,Matos, M. H.,Melo, M. A., Nair, S., Rodrigues, A. B., Silva, J. R. and Figueired, J.R.(2008). Preservation of bovine preantral follicle viability and ultra-structure after cooling and freezing of ovarian tissue. Animal Reproduction Science 108 (2008) 309-318

Cocero, M.J., de la Espina, M.D. and Aguilar, B.(2002). Ultrastructural characteristics of fresh and frozen-thawedovine embryos using two cryoprotectants. Biol. Reprod. 66, 12441258

Demirci, B., Salle, B., Frappart, L., Franck, M., Guerin, J.F. and Lornage, J. (2002). 
Morphologicalalterations

andDNA

fragmentation in oocytes from primordial and primary follicles after freezing-thawing of ovarian cortexi Adams, S.L., Kleinhans, F.W., Mladenov, P.V., Hessian, P.A., 2003. Membrane permeability characteristics andosmotic tolerance limits of sea urchin (Evechinus chloroticus) eggs. Cryobiology 47, 1-13. n sheep. Fertil. Steril. 77,595-600.

Fuku, E., Xia, L. and Downey, B.R., (1995). Ultrastructural changes in bovine oocytes cryopreserved by vitrification.Cryobiology 32, 139-156.

Fuller, B. and Paynter, S. (2004). Fundamentals of cryobiology in reproductive medicine. Reproductive BioMedicine Online 9, 680691.

Gookv, D.A. and Edgar, D.H. (1999). Effect of cooling rate and dehydration regimen on the histological appearance of human ovarian cortex following cryopreservation in 1, 2propanediol. Hum. Reprod. 14, 2061-2068.

Gosden, R.G., Baird, D.T., Wade, J.C. and Webb, R.(1994). Restoration of fertility to oophor-ectomized sheep by ovarian autographs stored at $-196^{\circ} \mathrm{C}$. Human Reproduction 9, 597-603.

Hay, M.F., Cran, D.G. and Moor, R.M., (1976). Structural changes occurring during atresia in sheep ovarian follicles.Cell Tissue Res. 169, 515-529

Karlsson, J.O.M. and Toner, M. (1996). Longterm storage of tissues by cryopreservation : critical issues. Biomaterials, Vol.17, 243-256,

Lucci, C.M., Kacinskis, M.A., Lopes, L.H.R., Rumpf, R. and Bao, S.N. (2004). Effect of different cryoprotectants on the structural preservation of follicles in frozen zebu bovine (Bos indicus) ovarian tissue. Theriogenology 61,1101-1114

Marsella, T., Sena, P., Xella, S., Marca, A., Giulini, S., De Pol, A., Volpe, A. and Marzona, L. (2008). Human ovarian tissue cryopreservation: effect of sucrose concentration on morphological features after thawing. Reproductive BioMedicine, 16(2): 257-267 (Online)
Matos, M.H.T., Andrade, E.R., Lucci, C.M., Bao, S.N., Silva, J.R.V., Santos, R.R., Ferreira, M.A.L.and Figueiredo, J.R., (2004). Morphological and ultrastructural analysis of sheep primordial follicles preserved in $0.9 \%$ saline solution and TCM 199. Theriogenology 62, 65-80

Newton, H., Fisher, J., Arnold, J.R., Pegg, D.E., Faddy, M.J. and Gosden, R.G., (1998). Permeation of human ovarian tissue with cryoprotective agents in preparation for cyopreservation. Hum. Reprod. 13, 376-378.

Oktay K, Newton H, Aubard Y, Salha O and Gosden RG. (1998). Cryopreservation of immature human oocytes and ovarian tissue: an emerging technology? Fertil. Steril., 69:17.

Paynter, S.J., Cooper, A., Fuller, B. and Shaw, R.W. (1999). Cryopreservation of bovine ovarian tissue: structural normality of follicles after thawing and culture in vitro. Cryobiology 38, 301-309

Rodrigues, A. P.; Amorim, C. A.; Costa, S. H.; Matos, M. H.; Santos, R. R.; Lucci, C. M.; Bao, S. N.; Ohashi, O. M. and Figueiredo, J. R. (2004). Cryopreservation of caprine ovarian tissue using dimethylsulphoxide and propanediol. Anim Reprod Sci, Vol.84, No.12, pp: 211-227

Santos, R.R., Rodrigues, Costa, H.S., Silva, G.R., Matos, M.H., Lucci, C.M, Bao, S.N., Hurk, R.V., and Figueiredo, J.R. (2006). Histological and ultrastructural analysis ofcryopreserved sheep preantral follicles. Animal Reproduction Science 91: 249-263

SAS, (1996). SAS/Stat. User's Guide Static's, Ver., 6.06, fourth ed. SAS Institute Inc., Cary, NC.

Scholmerich, J., Kitamura, S. and Miyai, K. (1989). Effects of propylene glycol on redox state of the perfused rat liver - a note of caution. Res. Exp. Med. 189, 39-42.

Silva, J.R.V., Bao, S.N., Lucci, C.M., Carvalho, F.C.A., Andrade, E.R., Ferreira, M.A.L. and Figueiredo, .R. (2001). Morphological and ultrastructural changes occurring during degeneration of goat preantral follicles preserved in vitro. Anim. Reprod. Sci. 66, 209-223 


\section{Cryopreservation of sheep ovarian tissue: Effect of different cryoprotectants and equilibration regimen on ovarian follicles structure}

Tassel, R. and Kennedy, J.P. (1980). Early follicular development and atretic changes in ovary of the lamb: in structureand histochemistry. Aust. J. Biol. Sci. 33, 675687.

Van Den Hurk, R., Spek, E.R., Hage, W.J., Fair, T., Ralph, J.H. and Schotanus, K. (1998).
Ultrastructure and viability of isolated bovine preantral follicles. Hum. Reprod. 4, 833-841

Wowk, B., Leitl, E., Rasch, C.M., MesbahKarimi, N., Harris, S.B. and Fahy, G. M. (2000) Vitrification enhancement by synthetic ice blocking agents. Cryobiology, 40(3):228-236

الملخص العربي

الحفظ بالتجميد لأنسجة مبيض الأغنام: تأثير عوامل الحماية من التجمد ونظام التجفيف على بنية حويصلات المبيض

$$
\begin{aligned}
& \text { إيهاب صلاح عبد العال } \\
& \text { معهد بحوث الإنتاج الحيواني - قسم بحوث الأغنام والماعز - الدقي - الجيزة }
\end{aligned}
$$

الهدف من هذه الدراسة هو تقييم كفاءة العوامل المختلفةالواقية من التجمد ، وكل من وقت التعرض ودرجة

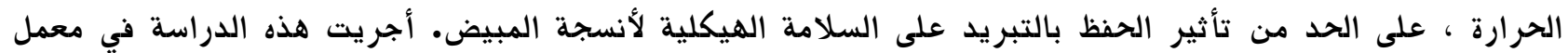

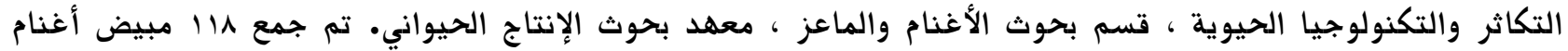

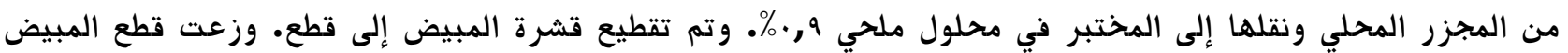

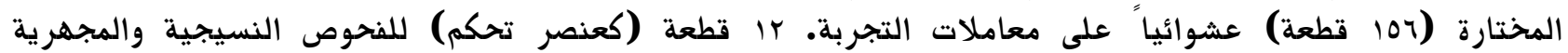

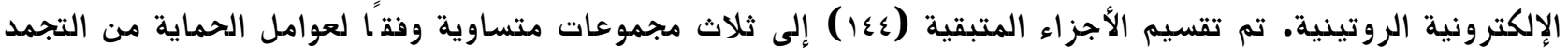

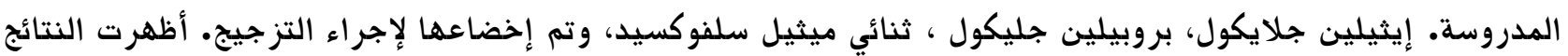

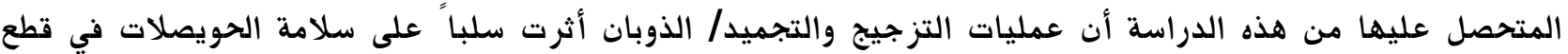

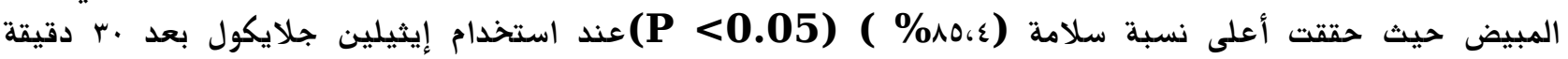

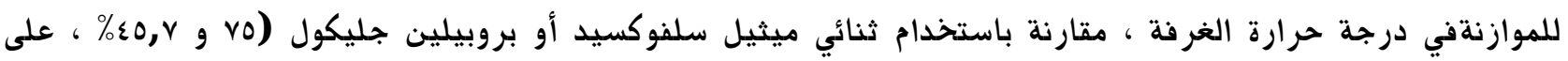

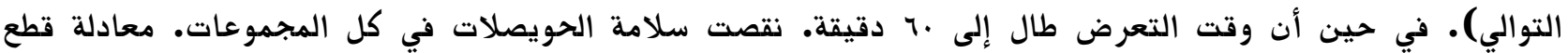

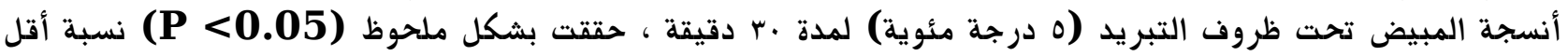

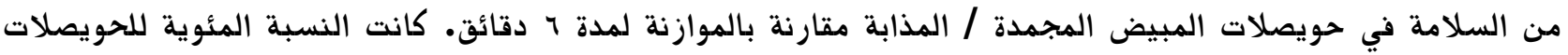

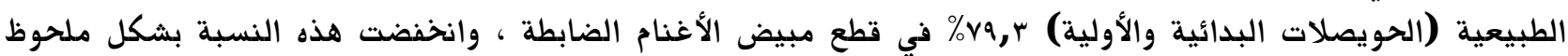

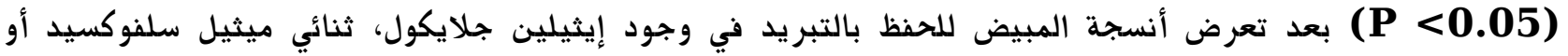
بروبيلين جليكول ، تحت فترات موازنة ودرجات حرارة مختلفة.

يمكننا أن نستنتج أن إيثيلين جلايكول يتبع ثنائي ميثيل سلفوكسيد هو أكثر المواد الواقية من التجمد ملاءمة التها

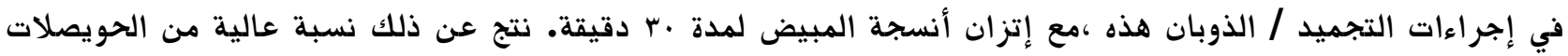

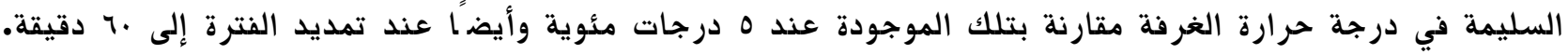

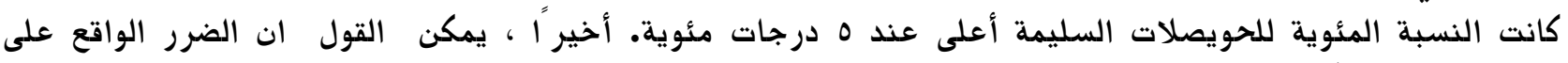
الحويصلات ناتجًا عن الواقي من التجمد أكثر من عملية الحفظ بالتبريد نفسلات التها. 